THURSDAY, MAY 13, 1880

\section{MIGRATORY BIRDS AT LIGHTHOUSES}

CONSIDERING the amount of nonsense that has been written and still continues to be written-in season and out of season-on the subject of the migration of birds, it is very refreshing to find two gentlemen in this country seriously setting to work to accumulate facts, which may in time be reasonably expccted to enable ornithologists to arrive at an opinion, more decided than anybody can be said to possess at the present moment, with regard to that wonderful movement. It might be thought, perhaps, that we indeed had already enough and to spare of recorded observations, for lists of the arrival of migratory birds abound in most of our natural-history periodicals, to say nothing of provincial newspapers; but it does not require much study and comparison of those lists to perceive that, with some honourable exceptions, they are obviously the work of persons not at all fittedwhether by character, training, or opportunities it matters not-to be competent observers, and consequently the records of their observations have done uncommonly little to advance our knowledge of the subject. Every one who has tried anything of the sort must admit, if he speaks the truth, that the difficultics in the way of observing the movements of birds are much greater than at first sight would appear to be the case. To carry on this kind of systematic obscrvation to any good purpose, a man, if he cannot make it his first object, must yet have such occupations as will not interfere with his being in the right place at the right moment, and of course the ordinary engagements of life are very apt to act as disturbing forces and to baffle his best intentions. Farmers, in the pursuit of their vocation, are perhaps of all professional men the most suited for the work; but the farmer may have to attend a couple of distant market-towns for as many days in the week, and unless his road thither and thence lies favourably, these will be dics non so far as his opportunities of observation are concerned. A very few years' experience will convince any sensible person that the first wheatcar of the season is almost always to be scen on a certain down or heath, and the earliest swallow over a certain pool or reach of a river. Localities like these, once discovered, have to be watched daily by him who wishes to record faithfully the arrival in his district of those particular species, and the same is to be said of others. Even the most enthusiastic sportsman may be hindered by a score of circumstances over which he has no control from visiting for a weck or more the particular spot in a copse or corner of a bog where, if there be a woodcock or a snipe in the country, he knows it is sure to be found. Seeing then that of the various kinds of outdoor observations few are more subject to the accidents which affect human actions and habits than those which relate to the movements of birds, the extremely unsatisfactory nature of records made in what is at best a casual way may be accounted for, and hitherto we have had scarcely any records of any other sort.

Some time ago it occurred to Mr. Cordcaux, author of that exccllent little book "The Birds of the Humber District," noticed in these columns some seven or eight VoL, XXII.-No. 550 years since (NATCRE, vol. viii. p. IOO), and to $\mathrm{Mr}$. Harvie Brown, a gentleman not less well known by his ornithological writings, that a great increase in our knowledge of the subject would accrue if they could but get the keepers of the numerous lighthouses and lightships along our coast to assist in the work, and accordingly they set about enlisting these men in the service. ${ }^{x}$ We know not whether these gentlemen had fully appreciated the unsatisfactory nature of existing records, upon which we have just been dwclling, nor does it signify in the least. It was evident to them, and might have been to others, that-men who were always on duty and always on the look-out would be able, if so minded and properly instructed, to give valuable aid, and that their observations would necessarily be of a kind that it was impossible for any other class of people to make, for they would be carried on at hours when nearly all the rest of the world was indoors, if not asleep, and at places at once the most favourable and the most inaccessible to any one else.

By what steps Messrs. Cordeaux and Brown proceeded, and how they overcame the scruples (if any werc entertained) of the authoritics of the Trinity Housc Board in England and of the Commissioners of Northern Lights in Scotland, we are not told; but these gentlemen have to be congratulated on the result they have attained, which appears in the form of a most instructive and interesting "Report"--the first, we hope, of a long series - "on the Migration of Birds in the Autumn of 1879 ," printed in the Zoologist for the current month, toiwhich we beg leave to call our readers' best attention. It appears that forms of inquiry and letfers of instruction were sent to various lighthouses and lightships. To begin with the east coast of Great Britain, it is said that such papers were forwarded to twenty-six Scottish lighthouses, from thirtcen, or just one-half, of which returns have been received, the remaining thirteen having either sent back the forms blank, owing to the unusual scarcity of birds last autumn, or having taken no notice of the request to fill them up. The same course was pursued with respect to thirty-sezcn English stations, from twenty-five of which returns have been received. On the west coast appeal was made to thirty-four Scottish stations, twentyfour of which replied, and to three on the Isle of Man (the Manxmen were silent), but to none in England or Wales. So much willing co-operation, we confess, ve could hardly have anticipated, especially on a first experiment, and it certainly appears from the intelligent rentarks (of which specimens are occasionally given by the reporters), in addition to the mere filling up of the sheets supplied to them, that the men must have taken considerable interest in the inquiry, as well as have taken no common pains in giving the information sought.

To form any conclusions on insufficient premisses is a rank offence in science, and it would be absurd to suppose that this single report throws any light on the mysteries of migration. But we are greatly mistaken if

I We give all credit to these gentlemen for the originality of action, but the conception of some rrch schene had been taken up before. Among the numerous inquiries in which Mr. J. H. (jurney, jun., had engaged himsclf, he had alrcady made some endeavcurs in this direction, and we are in a position to say thatevea prior to his time, though notbing came of it, the idea had been breached informally among some zoological members of the liritish Association for the Advancement of Science. Of this fact we, however, believe that Messrs. Brown and Cordeaux were not conscious, as indecd is could hardly happen that they should be. 
some of them may not be cleared up by a series of such reports, and the chief value of the present successful attempt is, in our humble opinion, to show that the plan put into operation by Messrs. Cordeaux and Brown is workable and we sincerely trust that they will continue their enterprising efforts. The amount of correspondence and trouble it must give them cannot fail to be very great, but they, as well as the lighthouse and lightship keepers, will have one kind of reward, and that, perhaps, one not altogether unsatisfactory. They will obtain the true gratitade of all ornithologists who believe in ornithology as a study of life, and we believe will receive from ornithologists without exception the credit and encouragement they so richly deserve. If the scheme can be kept going for half-a-dozen years we can scarcely fail to be in a position to know something worth knowing of the

. . . "wild birds that change

Their season in the night, and wail their way

From cloud to cloud," . . . .

whose movements at present give rise to so much speculation, and thereby, perhaps, penetrate another, and certainly one of the most interesting of nature's secrets.

\section{THE RIVER OF GOLDEN SAND}

The River of Golden Sand. By Capt. William Gill, R.E. With an Introductory Essay by Col. Henry Yule, C.B. R.E. (London : John Murray, Albemarle Street, I88o.) " THE River of Golden Sand," the narrative of a 1 journey through China and Eastern Tibet to Burmah, is likely to prove one of the most valuable books of travel that have been published for a considerable time. It is prefaced by a long and able introductory essay by Col. Yule. In it are indicated many points of geographical interest in the country in which the River of Golden Sand is taken as the axis-the part of Eastern Tibet which intervenes between India and China-and the history sketched of explorations in this extent of country previous to Capt. Gill's. This essay is so full of interest and information that we shall try to give a summary of the facts detailed in it.

The first thing that strikes an observant eye in looking at a map of Asia is the number of great rivers that rush southward in parallel courses within a very narrow space of longitude. This forms the most striking characteristic of the country between India and China. The first of these rivers, beginning at the west, is the Subanshiri, coming from the Himalaya and entering the valley of Assam. The next is the Dihong, which joins the Lohit-Brahmaputra proper-at Sadiya. The third river is the Dibong, which joins the Dihong before its union with the Brahmaputra. It is now believed that this does not come from Tibet. The people of Upper Tibet say they have only two rivers coming from Tibet-the Dihong and the Brahmaputra. The Brahmaputra enters Assam at the Pool of Brahma. This, from a curious piece of evidence given by Col. Yule, is evidently identical with Kenpu of Chinese geographers. The Ku-ts-Kiang is almost certainly a source of the Irawadi. The remotest sources of this river do not lie further north than $30^{\circ}$ at the utmost. Its length is considerably shorter than the River of Golden Sand. The Mekong has its source in the far north of Tibet. Its lower course has only been known accurately since the French expedition. But the town of Tsiamdo, standing between its two main branches about latitude $30^{\circ} 45^{\prime}$, was visited by missionaries in 1866 , so that its course is known as far north as this.

The Chin-Sha, from which Capt. Gill's book takes its name, is, if not the greatest river in Asia, the longest. Capt. Gill followed the windings of this river, with a few digressions, during twenty-four marches on his way from Bat'ang to $\mathrm{Xa}$-li-fu. This great river has its source in about $90^{\circ}$ longitude-almost as far west as Calcutta. At this part of its course its channel is $75^{\circ}$ feet wide, and the whole river from bank to bank nearly a mile wide. Flowing into China, it receives the name of Kin-ShaKiang, which it retains until joined by the Min, coming from Ssu-ch'uan. There it becomes navigable to the sea. The navigation has often many hindrances in the way of rapids and gorges. Capt. Gill was the first to give us any accurate knowledge of the Yun-nan and Tibetan part of this great river.

The remaining two parallel rivers are the Ya-lung-Kiang and the Min-Kiang. Capt. Gill is the only traveller that has traced the latter river to the alpine highlands.

How to obtain direct communication between India and China has always been a difficult problem. India first became known to China not across the mountains and through the river valleys, but by the enormous circuit of Bactria and Kabul. . In the year 127 B.C., Chang-Rien, a military leader, in exploring the country round the Oxus, brought back a report of a land called Shin-tu, i.e. Hindu, India. Attempts were made several times to penetrate by the Ssŭ-ch'uan frontier to India, but with little success. Two hundred years later, when communication opened with India, it was by way of Bactria, and went on so for centuries. In the "Periplus," a work of the first century A.D., mention is made of trade in silk stuffs through Bactria to Bhrōch. Marco Polo, when making his way to the frontier of Burma, went by the same route as Capt. Gill on his ninth march from Ch-eng-tu. Tali-fu, which is so often spoken of in Capt. Gill's book, is a central point on the Chinese frontier. For centuries it has been the centre of all military and commercial communication between China and Burmah.

By the treaty of Tien-tsing British subjects received the right to travel in the interior of China. Modern exploration dates from this, and our knowledge of the physical geography, natural resources of the country, and characteristics of the people of China have been slowly growing. It must not be forgotten that the missionaries of the Roman Church travelled much over China and Tibet. Publicity would have been against their purpose, and geographical research was not their object, so that their journals came before a limited few. Abbé Huc, in his famous story of his journey with Gabet, gave the first picture of Eastern Tibet in modern times in 1850. Carl Ritter's great work, which appeared many years before Huc's, gives a great deal of information of the great road by Ch'eng-tu to Lhassa. Apart from the little known efforts of the Roman Catholic missionaries, no attempt was made to penetrate those regions until i 86r. Blakiston's exploration of the Upper Yang-tzu, after the treaty of Tien-tsing, was the first in this direction. In 1867 the great French expedition to Ta-li under Garnier was made. This was the first time that any European 